SlavVaria 1/2021. 137-152

DOI: $10.15170 / S V .1 / 2021.137$

\author{
ЖОФИЯ КАЛАВСКИ \\ (Будапешт, Венгрия)
}

\title{
Истоки предания «Как Пушкин учился в школе». Замечания к московским легендам о Пушкине, записанным Евгением Барановым ${ }^{1}$
}

Аннотация: Данное исследование представляет собой анализ легенд о Пушкине, записанных в 1920-х годах в Москве этнографом Евгением Барановым. В этой работе я, в первую очередь, ищу источники, которые формировали у рассказчиков, выходцев из крестьян, образ Пушкина-героя в легенде «Как Пушкин учился в школе», а также отчасти в преданиях «Пушкин и царь», «Пушкин и Гоголь», «Как Пушкина жена погубила» и «Брюс, Сухарев и Пушкин». Предпринимается попытка показать, что один из первоисточников легенды «Как Пушкин учился в школе» находится в сохранившихся материалах первого курса Царскосельского лицея. Именно вариации одной тогдашней истории стали постоянными элементами популярных сборников анекдотов конца XIX века. Интересно тут не просто само филологическое исследование, но и отслеживание метаморфозы, в процессе которой литературный анекдот теряет все свои жанровые характеристики и превращается в «биографический» рассказ с главным героем. Анализ легенд, записанных Е. Барановым, сфокусирован на смыслообразующей силе московского памятника Пушкину и влиянии некоторых других легендарных московских личностей на рецепцию образа Пушкина.

Ключевые слова: литературный анекдот, популярный анекдот, предание, популяризованный образ Пушкина, культ Пушкина, памятник Пушкину, Москва

Рассказы о Пушкине сохранились благодаря этнографу Евгению Баранову (1869-после 1934). ${ }^{2}$ Он записывал их в Москве в начале 1920-х годов. Исследователь собирал свой материал в 1920-е годы в центре Москвы в дешевых столовых и чайных и просто на улицах вблизи Арбата. Легенды, связанные с прошлым города, и рассказы о русских писателях

\footnotetext{
1 Текст является дополненным и переработанным вариантом статьи, опубликованной на венгерском языке (см. KALAVSZKY 2020). Автор - научный сотрудник Центра Гуманитарных Исследований Института Литературоведения (BAH).

${ }^{2}$ В статье я ссылаюсь на издание БАРАНОВ 1993.
} 
ему рассказывали крестьяне, некоторое время жившие в Москве. Этнограф, будучи к этому времени уже ж инвалидом, зарабатывал на жизнь случайным образом: продавал с лотка подержанные книги, пел по трактирам. Он легко находил общий язык с людьми, приехавшими в город на заработки в надежде на лучшую жизнь - с домашней прислугой, нищими, извозчиками, уличными музыкантами, дворниками, трактирными лакеями - с теми, кто, подобно ему, скитался по стране, нищенствовал, побывал на фронтах давних и недавних войн. Москва 1920-х хранила ещё последние осколки царской России. Облик города, образ жизни, разговорный язык не были еще затронуты теми радикальными переменами (грандиозными советскими стройками и сносами, вторжением советского новояза), которые после революции, Гражданской и Первой мировой войны к середине 30-х коренным образом преобразуют, а точнее, сметут досоветскую Россию (БОКОВА 1993: 6-11).

Собеседниками Баранова, рассказы которых он записал между 1919 и 1923 гг., были неграмотные или полуграмотные крестьяне 40-60 лет, родившиеся во времена реформ середины XIX века. Экономические, правовые и политические реформы, начатые в 1860-х гг., радикально повлияли на все общество и, конечно, на составлявшее $80 \%$ населения крестьянство, на его образ жизни и мировоззрение, особенно резко изменившиеся с отменой крепостного права. В результате слой населения, который веками жил замкнутой общиной, стал мобилизовываться. Начиная с 1870-х гг. число людей, временно уезжавших в города из деревень, увеличилось, и постепенно между городским и сельским населением начал формироваться самостоятельный, промежуточный слой. Так называемые отходники представляли собой не только новый круг читателей, но также часто через их посредничество в деревнях стали появляться книги (РЕЙТБЛАТ 2009в: 133-145). Явление отходничества развивалось в основном вокруг экономически развитых городов с растущей промышленностью. Возросло также число крестьян, переселившихся в город: городское население в городах европейской территории России увеличилось в два раза. Все крестьяне, чьи рассказы записывал Е. Баранов, были отходниками:

«Коренных москвичей среди них почти не встречалось; почти все они были вчерашними крестьянами, почти все отдали дань беспокойной страсти к перемене мест, точно эпидемия, охватившей низовую Россию в середине прошлого века, и, словно восполняя предшествовавшие столетия вынужденной крепостной оседлости, вовлекшей огромные массы людей в бесконечное «броуновское движение», лишенное видимой цели. Героев Баранова долго гоняло ветром по всей России, пока не прибило в Москву, которая поглотила их, обтерла, отшлифовала и наложила в конце концов особенный, только ей присущий отпечаток» (БОКОВА 1993: 7). 
Это были люди, которые в трактирах или на войне могли слышать читавшиеся вслух произведения Пушкина или пересказы анекдотов о Пушкине. Им в руки также могли попасть лубочные книги, ${ }^{3}$ в которых публиковались переписанные произведения Пушкина, или же иллюстрированные газеты, журналы и сборники анекдотов, которые частично или полностью посвящены Пушкину.

Архив Е. Баранова сильно пострадал от пожара, случившегося в квартире этнографа в 1928 г. В наследии уцелели четыре с половиной, почти пять рассказов о Пушкине, так называемого московского «происхождения». Вслед за Е. Барановым литературоведение называет их легендами, понимая под легендой устную историю, в которой реальные биографические факты смешиваются с фиктивными элементами, с преобладанием последних. ${ }^{4}$

Далее мы сделаем попытку найти источники легенды «Как Пушкин учился в школе», записанной Е. Барановым. Мы постараемся разыскать те сведения, из которых мог родиться вырисовывающийся в этой истории образ Пушкина. Легенды могут формироваться из множества источников совершенно разного уровня и происхождения. Среди них можно назвать дешевые газеты, иллюстрированные журналы и популярные анекдоты, опубликованные в многотиражных сборниках анекдотов, городские сплетни и легенды, а также информацию о Пушкине, опубликованную в брошюрах и изданиях официальной царской пропаганды.

\section{Как Пушкин учился в школе}

Когда Пушкин учился в школе, учитель взял и посадил его на заднюю скамейку.

- Ты, говорит, и без учения много знаешь, - садись на заднюю скамейку, а которые остолопы - пускай на передней сидят, чтобы у меня перед глазами были и слушали мой урок.

Пушкин и говорит:

3 По данным Абрама Рейтблата Валентин Волгин (вероятно, псевдоним) - один из самых популярных авторов лубочной литературы. В 1883-1887 годы он под собственным именем публиковал подражания пушкинским повестям или обработки пушкинских произведений. В. Волгин обработал повесть «Станционный смотритель» под заглавием «Утопленница» (1887), поэму «Кавказский пленник» публиковал два раза под названием «Турецкий пленник» (1886), а затем под названием «Мертвец без гроба» (1887). Последний вариант пользовался большой популярностью и издавался 18 раз (РЕЙТБЛАТ 2009: 153).

4 Легенда, записанная Е. Барановым: «Брюс, Сухарев и Пушкин», рассказана 72летним Ф.Я. Болякиным, «Пушкин и Гоголь» рассказана А.Е. Колтыхиным, 4550 лет, «Как Пушкин учился в школе» рассказана В. Прокофьевичем, 40-60 лет, «Пушкин и царь» рассказана 60-летним Я. Иванычем, «Как Пушкина жена погубила» рассказана А. Кузнецовым 25 лет. 
- Так и так, мне все едино.

А после того учитель, этот профессор самый, и задает такой урок:

- Я, говорит, скажу вам свои слова, а вы на них скажете свои, только чтобы они в тахту [т. е. в такт, в рифму.] приходились. Ну вот, говорит, слушайте: «взошло солнце и освещает землю».

Теперь, говорит, скажите свои слова.

Вот ученики бились-бились, ничего у них не выходит. А было их триста человек. Профессор и говорит:

- Видно, без Пушкина дело не обойдется. Ну-ка, говорит, Пушкин, научи этих болванов в тахту сочинять.

А Пушкин говорит:

- У меня такие слова припасены, что всему классу не по нутру будут.

А профессор говорит:

-Ничего, не бойся, я за все в ответе.

Пушкин взял и сказал:

«Взошло солнце и освещает землю,

А вы, безумные народы, не знаете, что сказать».

Вот такую тахту сказал!

А ученикам не понравилось.

- Что же это, говорят, он один умный, а мы дураки? - И стали задирать его.

Профессору подсунули сотнягу, чтобы он их руку держал. Вот профессор и говорит раз:

- Что ж это ты, Пушкин, возвышаешься? Я, говорит, на что профессор, сколько университетов прошел, сколько академий, а не называю безумными. Только, говорит, ты мало смыслишь и до настоящих пунктов не дошел.

Вот, видишь, какая стерва, так-растак! Раньше Пушкин был хорош, а как взятку получил, Пушкина сажей вымазал! Пушкин слушал-слушал и рассердился:

- A, да ну вас к растакой матери вместе с вашей школой и профессорами! Я говорит, теперь над вами поднялся, а придет время, буду первый в России человек и не забудут меня вовек.

И ушел из школы сам по себе. И ведь правду сказал, что будет первым человеком: памятник поставили ему и все знают его (БАРАНОВ 1993: 133-135).

Предание «Как Пушкин учился в школе» представляет собой вариант общеизвестного популярного анекдота конца XIX века (см. например КРИВОШЛЫК 1896: 91; КОЗМАН 1901: 7-8). Этот же рассказ первоисточник вышеупомянутой легенды, которому более ста лет, - мы находим среди лицейских анекдотов о Пушкине. Общеизвестно, что 
Пушкин и его однокурсники в Царскосельском лицее редактировали, писали и создавали несколько рукописных журналов на протяжении шести лет лицейского обучения между 1811 и 1817 гг. (ГРОТ 1998: 283296, ЦЯВЛОВСКИЙ 1999: 461-563). Из этих рукописных журналов уцелело лишь несколько. Исключением является журнал «Лицейский мудрец», четыре номера которого за 1815 г. сохранились в переплете. В этом журнале, в разделе критики, был опубликован сатирический диалог «Исповедь Мясожорова», в котором содержится интересующая нас строка. ${ }^{5}$ Мясожоров - прозвище одного из лицеистов, Павла Мясоедова (1799-1868). Этот одноклассник Пушкина часто служил мишенью для насмешек в кругу школьных товарищей. ${ }^{6}$ Например, во всех карикатурах номеров «Лицейского мудреца» за 1815 год его последовательно изображали с ослиной головой.

В упомянутой сатире Мясоедов с ослиной головой жалуется священнику:

«Мясож.: Ах, батюшка [...] не только надо мной насмехаются, но и над моими стихами и прозой; но в доказательство несправедливости общего имения я вам прочту одно место из моих сочинений:

Блеснул на западе румяный царь природы...

Поп: Ошибка, ошибка; на востоце, а не на западе. Возтекаю orior» (ГРОТ 1998: 349).

Редакторы «Лицейского мудреца», точнее автор(ы) сатиры, развёртывают аллегорию «глупого осла», объектом насмешки выступает семантическое противоречие: Мясожоров не замечает, что Солнце («румяный царь природы») на западе может только садиться, а не вставать (см. «блеснуть»). Пародия строится и на том, что восторженный стихотворец пытается следовать главному поэтическому идеалу эпохи: стремится создать свое стихотворение в высшем стиле риторики классицизма - в высоком -, но употребляет клише этого стиля (см. солнце, как румяный царь природы, блеснуло), не согласовав его семантически с предшествующим словом «на западе».

Константин Грот в 1911 г. издал уцелевшие документы первого курса Царскосельского лицея, собранные его отцом, Яковом Гротом. В сбор-

5 «Лицейский Мудрец», издававшийся Данзасом, Корсаковым, Мартиновым и Ржевским, был юмористическим журналом и, по словам Корфа, »самым площадным « из всех лицейских журналов» (ЦЯВЛОВСКИЙ 1999: 482).

${ }^{6}$ Лицейские прозвища Мясоедова: Меринос, Глупон, Мясожоров, Осло-Домясов. Отзыв Василия Малиновского, первого директора Лицея: «Способности его весьма ограничены; слабого понятия, слабой памяти, самолюбив, докучлив, пылок» (ГРОТ 1998: 411). 
нике, который является по сей день уникальным литературным источником, к этому отрывку сатиры он добавил следующую сноску:

«Известно предание, что так начал, но не умел продолжить свои стихи Мясоедов на заданную однажды ученикам проф. Кошанским тему «восход солнца», и что, видев его затруднение, кто-то из товарищей (по Гаевскому, это был Илличевский, а не Пушкин) дополнил их так:

И изумленные народы

Не знают, что начать:

Ложиться спать или вставать».

(ГРОТ 1998: 349)

Из сноски Грота мы узнаем историю того события на уроке, которое послужило источником сатиры: в ней юный Пушкин дополняет опус Мясоедова неожиданной концовкой-эпиграммой, изобличающей его глупость, благодаря чему она и становится анекдотом. Пушкин или его одноклассник Илличевский, сразу заметив логическую ошибку и мгновенно отреагировав на нее, - в отличие от священника в сатире, который лишь вздыхает, выслушав строчку, - высмеивает товарища в форме поэтической травестии, и, таким образом, история превращается в классический литературный анекдот, жанр, который к концу XVIII-го - началу XIX века имел уже четко отработанную и устоявшуюся поэтику (КУРГАНОВ 1995).

Анекдот к тому же имеет еще один слой значения, который для Пушкина и лицеистов-редакторов, поэтов был совершенно очевидным контекстом. Это проходившая в 1810-х гг. литературная полемика, которая велась между архаистами, то есть обществом «Беседы любителей русского слова» и литературной группировкой, позже объединившейся в кружок «Арзамас» и пропагандировавшей новое, романтическое направление. Виктор Гаевский (1826-1888) однозначно приписывал продолжение стихотворения Илличевскому, а не Пушкину. После публикации анекдота он написал в 1863 г. в журнале «Современник» следующее:

«Справедливость требует однакож заметить, что знаменитая фраза не принадлежит M_ву, а была не кстати похищена им у А.П. Буниной. В собрании ее произведений, изданных в 1809 под заглавием «Неопытная Муза», находим элегию «Сумерки», начинающуюся стихом: «Блеснул на западе румяный царь природы» навлекшим гонения на неразборчивого похитителя» (ГАЕВСКИЙ 1863: 145).

Стихотворения поэтессы Анны Буниной (1774-1829) в глазах лицеистов считались образцами отсталой, устаревшей поэзии. Пушкин высмеивает поэтессу в стихотворении «Послание цензору» (1822). 
В первой половине XIX века в замкнутом обществе Царскосельских лицеистов анекдот имел двойной смысл: высмеивание Мясоедова, с одной стороны, и укол в адрес поэтов, принадлежавших к архаистам, с другой. Конечно, помимо этого - косвенным образом - анекдот ставит памятник бойкости, быстрой реакции, чувству юмора и остроте ума Пушкина, (а по другим воспоминаниям - Илличевского). Позже, в течение XIX века, среди постоянно рождающихся анекдотов про Пушкина этот анекдот удачно дополняет образ Пушкина-острослова.

Несмотря на то что вышеописанный анекдот был издан не раз во второй половине XIX века в различных журналах, ${ }^{7}$ публикации, релевантные с точки зрения массовой известности, появлялись на рубеже XIX-XX веков и в первое десятилетие XX-го. Городской малообразованный читатель встречался с ними не в так называемой серьезной прессе, толстой периодике, исторических и литературных журналах, а в других изданиях. Популярность анекдота, его частое переиздание объясняется формированием государственного культа Пушкина, а точнее, становится его побочным явлением: „производство Пушкина” было поддержано лёгкими, короткими, ориентированными на сенсацию, необычность и оригинальность рассказами о Пушкине в дешевых бульварных газетах и в развлекательных иллюстрированных журналах. Конец XIX века, а особенно 1899-й, юбилейный с этой точки зрения год был особенно выдающимся. Эти истории постоянно присутствовали в изданиях недорогой, так называемой малой прессе и прочих массовых печатных изданиях.

Одной из форм малой прессы были дешевые, 2-3-х копеечные газеты, выходившие несколько раз в неделю. Они содержали развлекательные, легко воспринимаемые материалы и были ориентированы не на высокообразованную публику, а на «стоящие на самых низких ступенях социальной лестницы слои городского населения» (РЕЙТБЛАТ 2009а: 116). В таких газетах регулярно печатались анекдоты о Пушкине. Например, одной из таких газет была «Сын отечества» (1862-1905). ${ }^{8}$

Другим типом газеты, популярной в те времена, был тонкий, иллюстрированный еженедельник. Он тоже издавался для малообразованных, с трудом пишущих и читающих слоев населения и служил развлечением городским низам. Эти газеты продолжали традиции лубочных изданий, популярных среди читателей крестьянского происхождения, и были сделаны на манер «The Illustrated London News». Основную часть таких газет составляли иллюстрации (портреты, пейзажи, репродукции картин), а меньшую часть - коротенькие тексты (преиму-

\footnotetext{
${ }^{7}$ См. в «Москвитянине» от 1-ого февраля 1853 г., в 117-м номере 1854 г. в «Московских ведомостей», в 10-ом номере 1888 г. «Русской старины».

8 O сведениях про Пушкина в печати конца XIX начала XX века мной были использованы данные двух библиографий см. ФОМИН 1929; БЕРКОВ, ЛАВРОВ 1949.
} 
щественно подписи под иллюстрациями). К рубежу XIX-XX веков у газет этого типа было уже 500 тыс. подписчиков. Каждая из них переиздавала материалы так называемой серьезной периодики, но в упрощенной, сокращенной и переписанной форме, при этом приоритет отдавался занимательности и развлекательности (РЕЙТБЛАТ 2009б: 101-112), см. журналы «Всемирная иллюстрация» или «Иллюстрированный мир» и опубликованные в них анекдоты про Пушкина в 1886, 1891 и 1895 гг. (БЕРКОВ, ЛАВРОВ 1949). Сходным с упомянутыми журналами был и журнал «Досуг и дело», который издавался в первую очередь для рядовых солдат и который тоже публиковал истории о Пушкине.

Наконец, в распространении анекдотов про Пушкина важную роль сыграл популярный тип книги, удовлетворявшей одновременно просветительским и развлекательным целям. Такие книги переходили из рук в руки, многие экземпляры читались по стольку раз, что буквально рассыпались в руках. Это были так называемые массовые печатные издания, собрания анекдотов, которые имели огромную популярность среди городских малообразованных читателей, имеющих пристрастие к необычному, фантастичному и занимательному. Эти книги издавались в соответствии с читательским спросом. На их страницах печатались истории «из жизни» знаменитых людей, великих личностей российской истории и Пушкина в том числе (см. например СУВОРИН 1885; МИХАЙЛОВВИКТОРОВ 1886), а ближе к рубежу столетия - часто без указания на оригинальный источник, в различных вариантах и с меняющимся содержанием, под именами разных редакторов, составителей - в массовой печати появились отдельные и многократно издающиеся сборники анекдотов про Пушкина (напр. КРИВОШЛЫКЪ 1896; АНИСИМОВ 1899; ШЕВЛЯКОВ 1899; КОЗМАН 1901; ВАЗАРИН 1907).

Источник записанной Е. Барановым легенды о Пушкине за сто лет прошел различные устные и письменные каналы процессов наследия, а затем перекочевал в радикально иную среду восприятия. За это время перетерпел немалые изменения и утраты значения. Из него исчезло как раз то, что являлось его фокальной точкой - ошибка, в которой путается запад и восток (садящееся-восходящее Солнце), и направленный на разоблачение этой ошибки pointe, в следствие чего анекдот утратил характер апофегмы. ${ }^{9}$ Языковой каламбур Пушкина/Илличевского деформировался. Эпиграмма, выполнявшая роль неожиданной концовки, сократилась и превратилась в единственную, лишенную смысла строчку, утратив языковую игру, остроту мысли. В силу амплификации, то есть дополнения, расширения анекдот превратился в рассказ, утратилась его первоначальная структура, изящность, краткость - иными словами, он

9 Об исторической связи апофегмы и русского литературного анекдота см. КУРГАНОВ 1995: 23-33. 
перестал быть художественно преобразованным текстом. ${ }^{10}$ Центр тяжести в легенде, записанной Е. Барановым, сместился на образ самого Пушкина, цели создания которого не было и не могло быть в оригинальном анекдоте, так как сам жанр классического литературного анекдота подразумевает (псевдо)диалог, которая завершается, заканчивается неожиданным, непредсказуемым ответом (сентенцией, эпиграммой и т.д.) из другого логического ряда, а не рассказ, укрепляющий репутацию некоего героя. Эта же легенда ставит в центр внимания образ Пушкина, сосредотачивается на его словах и поведении. Центр внимания перемещен на основные качества Пушкина, его интеллект, независимость, чувство собственного достоинства, а также на его способность одержать победу над враждебной окружающей средой. Кроме этого, рассказчик легенды приписывает Пушкину пророческий дар (См. «и ведь правду сказал, что будет первым человеком» БАРАНОВ 1993: 135). Таким образом, анекдот как жанр потускнел, перешел на задний план, стал лишь поводом для рассказа истории биографического характера.

Очевидно, что вырисовывающийся в легенде образ Пушкинаострослова с чувством собственного достоинства, кроме лицейского анекдота, мог иметь и другие источники. Одним из них являются строки стихотворения Пушкина «Памятник». Крестьяне-собеседники Е. Баранова, как это выясняется из остальных записанных им рассказов, были знакомы с памятником Пушкину на Тверской площади. В последнем абзаце приведенной выше легенды рассказчик, в сущности, говорит о памятнике Пушкину и воспроизводит краткий пересказ стихотворения поэта: «Я, говорит, теперь над вами поднялся, а придет время, буду первый в России человек и не забудут меня вовек.» (БАРАНОВ 1993: 135). (Ср. «Я памятник себе воздвиг нерукотворный [...] Слух обо мне пройдет по всей Руси великой»). ${ }^{11}$ На пьедестале открытого в 1880 г. памятника Пушкину на Тверском бульваре высечено несколько строк из стихотворения Пушкина «Памятник». ${ }^{12}$ С этого момента фрагмент стихотворения в массовом сознании сросся с памятником и начал самостоятельную жизнь. ${ }^{13}$ Пушкинские строки, которые написаны в 1836 г., с 1880 г. стали неотделимы от бронзовой скульптуры, возвышающейся над людьми и „обращающейся к ним”. Некоторые и по сей день

10 О связи риторической амплификации и потере характера анекдота см. GOSSMAN 2009: 219.

${ }^{11}$ На пьедестале были высечены строки: «Слух обо мне пройдет по всей Руси великой / И назовет меня всяк сущий в ней язык», «И долго буду тем народу я любезен,/ Что чувства добрые я лирой пробуждал» /. В 1936 году их заменили на оригинальные строки: «И долго буду тем любезен я народу».

${ }^{12}$ О чествовании Пушкина и памятника в 1880 году см. ЛЕВИТТ 1994.

13 См. стихотворения поэтов «третьего ряда» 1880-х годов цитирующие строки «Памятника». КАЛЛАШ 1899. 
отождествляют многие строки стихотворения с этой конкретной скульптурой. Памятник поэту стал московским местом паломничества, где можно чтить память Пушкина. Он заполнил собой пространство «отсутствия» могилы Пушкина. (МОЛОК 2000: 12-15). Говоря о «всезнании» Пушкина, «крестьяне Баранова» часто приводят существование памятника Пушкину в качестве аргумента: «Человек умнейший был, а иначе нешто поставили бы ему памятник?» (БАРАНОВ 1993: 129) Этот вопрос задает Е. Баранову один пожилой собеседник во время рассказа легенды «Брюс, Сухарев и Пушкин». А другой крестьянин заканчивает легенду «Пушкин и царь» следующими словами: «Он, говорит, справедливый человек был, он за крестьян стоял. Вот поставили ему памятник» (БАРАНОВ 1993: 139).

Разумеется, в корпусе популярных сборников анекдотов можно выявить и дальнейшие предшествующие мотивы и сюжетные элементы предмета нашего анализа. Образ Пушкина, как сознательной, гордой, выдающейся личности, хранился множеством популярных анекдотов. Упомянем два самых известных из них. Оба эти анекдота часто печатались в одном сборнике вместе с лицейским анекдотом. Один из них - по своему происхождению тоже литературный анекдот - заканчивается знаменитым высказыванием Пушкина:

«Один лицеист вскоре после выпуска из императорского Царскосельского лицея, в 1829 году, встретил Пушкина на Невском проспекте. Поэт, увидав на нем лицейский мундир, подошел и спросил:

- Вы, вероятно, только что выпущены из лицея?

- Да, только что выпущен с прикомандированием к гвардейскому полку, - ответил лицеист и в свою очередь спросил: - Вы тоже воспитывались в нашем лицее?

- Да.

- А позвольте спросить вас, где вы теперь служите?

- Я числюсь по России, - ответил Пушкин» (ГЕССЕН, МОДЗАЛЕВСКИЙ 1991: 138). ${ }^{14}$

Другой известный анекдот, печатавшийся то в более коротком, то в более длинном варианте, сложился из нескольких воспоминаний современников Пушкина и помещает в центр внимания ум Пушкина и его хорошие отношения с царем (чем в 1899 г. преследовались сугубо пропагандистские цели). Текст заканчивался следующим изречением Николая I о Пушкине: «Сегодня я говорил с умнейшим человеком в России.

14 Этот анекдот многократно публиковался см. нп. МИХАЙЛОВ-ВИКТОРОВ 1886: 291; КРИВОШЛЫК 1896: 92; КОЗМАН 1901: 7. 
С Пушкиным». ${ }^{15}$ Следовательно, легенды Баранова отнюдь не случайно отражают образ Пушкина, как самого умного человека («он всю нашу науку превзошел», «золотая у него голова»).

Представление о том, что Пушкин мог предсказывать будущее, может иметь множество источников. Лексиколог и диалектолог В. И. Чернышев, собиравший материал в «Пушкинском уголке» в 1927 г., отметил, что не раз встречался в кругу местного населения с убеждением о том, что Пушкин предвидел будущее. (См. образ Пушкина-чародея). Чаще всего упоминались два события - отмена крепостного права (например, «Он говорил, что придет время и год назначил, когда будет, что землю у помещиков отберут для крестьян», ЧЕРНЫШЕВ 1928: 350) и собственная ранняя смерть. В.И. Чернышев часто сталкивался с тем, что высказывания произведений и стихотворений Пушкина отождествляли с самим поэтом, например, предсказание о ранней смерти объяснялось стихотворением «Умолкну скоро я...». Наивное восприятие такого же типа мы видим в рецепции стихотворения «Памятник». Однако крестьяне, с которыми разговаривал Баранов - судя по информации этнографа - совершенно не были знакомы с произведениями Пушкина или были знакомы только в очень небольшой степени. Поэтому в создании образа Пушкина-пророка мы считаем наиболее значимым тот фактор, что московский городской фольклор сблизил Пушкина с другими легендарными личностями так, что их свойства частично переносились на образ Пушкина. Одной такой личностью мог быть Яков Вилимович Брюс (1669-1735), главный персонаж множества московских легенд, записанных Е. Барановым. О силе легенд, связанных с Брюсом, свидетельствует и приведенное Чернышевым высказывание о Пушкине, в котором последний упоминается вместе с Брюсом. Источником этого высказывания мог быть только московский фольклор. См. «Один старик мне говорил: Пушкин был такой человек, который вперед все знал, что будет, все равно, как Брюс. Которая вот теперь сотворилась разруха, он ее знал и описал» (ЧЕРНЫШЕВ 1928: 350. Курсив мой - Ж.К.). Яков Брюс в московском городском фольклоре был связан с черной магией, он был «колдун в Сухаревой башне». ${ }^{16}$ Этот дар пророчества был перенесен на Пушкина. Пушкин и Брюс не раз фигурируют вместе в московском фольклоре. Один из рассказчиков Е. Баранова прямо так и начинает свою легенду: «Их было трое: Брюс, Сухарев и Пушкин...» (БАРАНОВ 1993: 127).

Корпус записанных Е. Барановым и сохранившихся московских городских легенд о Пушкине, разумеется, ни в каком смысле не может считаться репрезентативным, но анализ имеющихся легенд все же дает возможность сделать несколько выводов.

${ }^{15}$ МИХАЙЛОВ-ВИКТОРОВ 1886: 291-292. См. еще КРИВОШЛЫК 1896: 93; КОЗМАН 1901: 32-33.

${ }^{16}$ Об образе Брюса подробно см. БОКОВА 1993: 8-9. 
Во-первых, в них чувствуется влияние процеженных через опыт городской жизни популярных историко-биографических анекдотов про Пушкина. Наблюдается (заново) фольклоризация рассказов, некогда записанных представителями литературной элиты. И хотя образу Пушкина в этих легендах в большей или меньшей степени присущи черты архаического шута (преимущественно в легенде «Пушкин и царь»), тем не менее их нельзя причислить к корпусу «анекдотов о шутах», характерных для XVIII века. (Они не являются анекдотами.) Среди них нет также эротических, скатологических рассказов, похожих на записанные фольклористом Н.Е. Ончуковым (1872-1942) в городе Сарапуле в 1880-х гг. (БЕЛОУСОВ 2001, ПАНЧЕНКО 2011: 401).

Лексика и стилистика записанных Е. Барановым рассказов местами лишь простые, разговорные, но есть и тексты, буквально кишащие неправильностями, бранными и жаргонными словами, и хотя все они отражают малограмотность говорящего, разброс в языковом оформлении, осмыслении, стилистике довольно велик; важны здесь, очевидно, не только индивидуальность, способности, образованность, но и возраст рассказчика. Например, легенда «Пушкин и царь» имеет четкую структуру, содержит множество фольклорных элементов, а легенда «Как жена Пушкина погубила», которую рассказал самый молодой, 25-летний рассказчик, родившийся на рубеже XIX века, самая слабая в языковом отношении. Однако эта легенда является самой современной, самой секуляризованной и в наибольшей мере отражает городской взгляд на жизнь.

Далее, важной характеристикой легенд является то, что все они сильно отличаются от материалов, собранных В.И. Чернышевым у крестьян, которые жили бывшем пушкинском имении. Самое существенное отличие, очевидно, объясняется тем, что «легенды Е. Баранова» родились в полукрестьянском-полугородском образе жизни, и в связи с этим мы не можем говорить о прямом влиянии официального культа Пушкина и агрессивной, непосредственной пропаганды. Это влияние наблюдается в них лишь косвенно, как побочное, посредничающее культурное влияние пропагандистской машины. Этого нельзя сказать в отношении крестьян-собеседников В.И. Чернышева. Более того, как отмечет сам В.И. Чернышев, со второй половины XIX века приезжавшие в имение группы интеллигенции, проходившие здесь юбилеи и собрания на протяжении десятков лет оказывали активное и непосредственное влияние на отношение местного крестьянства к Пушкину. В связи с чем наивно было бы полагать, что в конце 1920-х годов здесь ещё возможно исследовать чисто народный, интуитивный образ Пушкина. Соглашаясь с написанным Александром Панченко, полевые работы В.И. Чернышева и их описания «это хорошо документированная история „снижения культурных ценностей”, позволяющая проследить, как литературно-политическая мифология, навязываемая крестьянам образованной и обладающей 
властными полномочиями элитой, адаптируется к социальным ожиданиям и нарративным практикам деревенской общины. Эти описания также показывают, что именно из „канонических сюжетов” и коллизий идеологизированной истории русской литературы могло представлять интерес для рассказчика из крестьянской среды и за счет каких средств мог удовлетворяться официальный спрос на „народную любовь к Пушкину”» (ПАНЧЕНКО 2011: 410).

При формировании легенд, записанных Е. Барановым, надо обязательно учитывать присутствие конкретной московской городской среды, экономические, общественные и моральные вопросы, которые были интересны в этой среде. Этот интерес проявляется и в выборе тех сюжетных элементов биографии Пушкина, которые стали пересказываться в легендах. Все скандальное или занимательное обретало в легендах центральное место: мотив доносов, клеветы и заговоров против Пушкина (встречается в сюжете четырех легенд); некрасивая внешность поэта («он нехорош») и происхождение («арапская кровь»), а также мотив хитрой, но красивой злодейки-жены и образ богатого полковника, который в конце концов причинил ему смерть. В них исключительно сильно чувствуется практичный, сосредоточенный на выживании образ мысли городской жизни. В то же время эти рассказы тесно связаны с самим городом, и в этом контексте напрашивается интерпретация Пушкина, связанная с памятником, стоящим в конце Тверского бульвара, скульптуры, которая ещё в 1920-е гг. стала самостоятельным фактом культуры, частью городского фольклора и порождала московские истории (МОЛОК 2000: 16-20). Соглашаясь с Верой Боковой, Пушкин существует в московских легендах не в роли поэта, а в роли героя, которого поминают как того, кто

«застроил Москву, завел в ней порядок, помогал править государством, был самым умным из людей, стоял за правду, за народ и за это сидел в тюрьме... В нем все должно быть исключительно - и происхождение, и жизнь, и смерть» (БОКОВА 1993: 11).

В качестве заключения нам хотелось бы упомянуть сюжетный мотив, который совершенно неорганично присутствует в легенде «Пушкин и Гоголь». Пушкин на смертном одре дарит Гоголю часы. ${ }^{17}$ Эта сцена является не только хорошим примером запутанного совмещения информации, полученной из разных источников, но и хорошо иллюстрирует отличие представлений о ценности предметов в модернизирующейся городской и в деревенской-простонародной жизни. Мотив дарения Пушкиным подарка на смертном одре имеет источники среди литературных анекдотов, но в них дарятся не часы, а некий конкретный перстень. В на-

${ }^{17}$ Гоголь во время смерти Пушкина находился заграницей. 
чале XX века в формах различных вариаций литературного анекдота ходил рассказ, в котором Пушкин на смертном одре достал из коробочки и подарил своему секунданту Данзасу перстень, полученный от их общего друга, В.А. Нащокина. Перстень якобы являлся талисманом, защищающим от насильственной смерти. Эта история была опубликована впервые В.А. Нащокиным в «Воспоминаниях о Пушкине и Гоголе» в 1898 г., а после этого во многих других изданиях на рубеже веков, а также в 1923 г. (ГЕССЕН, МОДЗАЛЕВСКИЙ 1991: 278). Вероятно, в легенду, записанную Е. Барановым, часы попали как статусный символ городской жизни. Мотив часов снова и снова возникает не только в биографии Пушкина (см. лицейскую историю, в которой за сочинение куплета Пушкин получил золотые часы с цепочкой; из этой истории выросло ещё одно предание, ПУШКИН 1999: 687), но и в литературной пушкинистике. По крайней мере это происходит с момента появления третьего анекдота Даниила Хармса про часы Петрушевского. Но это уже предмет другого анализа. «Стоп машина!»

\section{Литература}

АНИСИМОВ А.А. (ред.) (1899) Анекдоты изъ жизни Пушкина. Типография И.Я. Полякова. Москва, 1899.

БАРАНОВ Е. (1993) Московские легенды, записанные Евгением Барановым. Бокова В. (вступ. статья, сост.), Буртин Ю. (ред.) Москва: Литература и политика, 1993.

ВАЗАРИН 3. (1907) Анекдоты про А.С. Пушкина никогда еще до сих пор не печатанные. Тифлис, 1907.

БЕЛОУСОВ А.Ф. (2001) Из истории фольклорных анекдотов о Пушкине // Труды факультета этнологии, 1. Санкт-Петербург, 2001. 211-213.

БЕРКОВ П.Н., ЛАВРОВ В.М. (1949) Анекдоты о Пушкине // Томашевский Б.В. (ред.) Библиография произведений А.С. Пушкина и литературы о нем 18861899. Москва, Ленинград, 1949. 317-323.

БОКОВА В. (1993) Вступительная статья // Баранов Е. Московские легенды, записанные Евгением Барановым, Бокова В. (вступ. статья, сост.), Буртин Ю. (ред.) Москва, 1993. 5-11.

ГАЕВСКИЙ В.П. (1863) Пушкин в Лицее и лицейские его стихотворения // Современник, 97, 7-8 (1863): 129-177.

ГЕССЕН С., МОДЗАЛЕВСКИЙ Л. (ред.) (1991) Разговоры Пушкина: Репринт. воспроизведение изд. 1929 г. Москва, 1991.

ГРОТ К.Я. (1998) Пушкинский лицей. Санкт-Петербург, 1998.

КАЛЛАШ В. (1899) Русские поэты о Пушкине (Сборник стихотворений). Москва, 1899.

КОЗМАН М. (1901) Шутки и остроты А.С. Пушкина: полное собрание анекдотов, острот, шуток, экспромтов и эпиграмм. Одесса, 1901.

КРИВОШЛЫКъ М.Г. (1896) Александръ Сергъевичъ Пушкинъ (биография и 18 анекдотов) // Исторические анекдоты изъ жизни русских замечательных людей (Съ краткими біографіями их). Санкт-Петербургъ, 1896. 89-101. 
КУРГАНОВ Е. (1995) Литературный анекдот Пушкинской эпохи // Slavica Helsingiensia, 15. Helsinki: Helsinki University Press, 1995.

ЛЕВИТТ М.Ч. (1994) Литература и политика: Пушкинский праздник 1880 года Санкт-Петербург, 1994 .

МИХАЙЛОВ-ВИКТОРОВ (1886) Собрание анекдотов из жизни государей, князей, министров, полководцев, генералов, ученых, философов, писателей, художников, композиторов, артистов и других замечательных лиц. СанктПетербург, 1886.

МОЛОК, Ю.А. (2000) Пушкин в 1937 году. Материалы и исследования по иконографии. Москва, 2000.

ПАНЧЕНКО А. (2011) Пушкин в советском фольклоре // Лавров А.В (ред.) Культурный палимпсест. Сборник статей к 60-летию Всеволода Евгеньевича Багно. Санкт-Петербург, 2011. 390-410.

ПУШКИН А.С. (1999) Примечания к стихотворению «Принцу Оранскому» // Пушкин А.С., Полное собрание сочинений в двадцати томах. Лицейские стихотворения (1813-1817). Санкт-Петербург, 1999. 687.

РЕЙТБЛАТ А.И. (2009а) Газета в низовой читательской среде // Рейтблат А.И. От Бовы к Бальмонту: Очерки по истории чтения в России во второй половине ХІХ века. Москва, 2009. 113-132.

РЕЙТБЛАТ А.И. (2009б) Иллюстрированный еженедельник и его подписчик // Рейтблат А.И. От Бовы к Бальмонту: Очерки по истории чтения в России во второй половине XIX века. Москва, 2009. 101-112.

РЕЙТБЛАТ А.И. (2009в) Книга и крестьянин: изменение отношения к чтению // Рейтблат А.И. От Бовы к Бальмонту: Очерки по истории чтения в России во второй половине ХІХ века. Москва, 2009. 133-145.

РЕЙТБЛАТ А.И. (2009г) Лубочная книга и крестьянский читатель // Рейтблат А.И. От Бовы к Бальмонту: Очерки по истории чтения в России во второй половине ХІХ века. Москва, 2009. 146-169.

СУВОРИН А.С. (1885) Пушкин // Суворин А.С. Исторические рассказы и анекдоты из жизни русских государей и замечательных людей XVIII и XIX столетий. (Изд. 2-ое) Санкт-Петербург, 1885. 317-322.

ФОМИН А.Г. (1929) Puschkiniana 1900-1910. Ленинград, 1929.

ЦЯВЛОВСКИЙ М.А. (1999) Источники текстов лицейских стихотворений // Вацуро В.Э. (ред.) А.С. Пушкин, Полное собрание сочинений в двадцати томах. Лицейские стихотворения (1813-1817). Санкт-Петербург, 1999. 461563.

ЧЕРНЫШЕВ В.И. (1928) «Пушкинский уголок», его быт и предания // Известия Русского Географического Общества, 2. 60. Ленинград, Москва, 1928. 327360.

GOSSMAN L. (2009) Anekdota és történelem // Kisantal T. (szerk.) Narratívák 8. Elbeszélés, kultúra, történelem, Budapest, 2009. 217-249. (Original: Gossman, Lionel: Anecdote and History. History and Theory, 2003/May, 143-168). DOI: 10.1111/1468-2303.00237

KALAVSZKY ZS. (2020) „És nyugaton felragyogott a természet vörös cárja”. Megjegyzések az 1920-as években gyüjtött, moszkvai Puskin-legendákhoz // Csörsz R.I. (szerk.) Doromb. Közköltészeti tanulmányok 8. Budapest, 2020. 147-164. 
The sources of the legend "How Pushkin studied in school". Reflections on the Pushkin legends noted down by Evgeny Baranov in Moscow. In my study I analyze the Pushkin legends noted down by Russian ethnographer Evgeny Baranov in the 1920s in Moscow. My research primarily focuses on the myth "How Pushkin studied in school", although I also partly discuss what sources the peasant-born speakers could have used when forming their Pushkin image in the myths "Pushkin and the tsar", "Pushkin and Gogol", "How Pushkin was taken out by his wife", and "Bruce, Sukharev, and Pushkin". I demonstrate how the legend "Как Пушкин учился в школе” ("How Pushkin studied in school") has a primary source in the materials surviving from the first year of the Tsarskoye Selo lyceum, variants of which became perennial pieces in the popular anecdote collections of the end of the nineteenth century. Beyond the philological investigation it is especially interesting to follow the metamorphosis during which the literary anecdote loses its generic characteristics and expands into a "biographic" story on a central protagonist. The analysis of the Baranov myths draws attention to the power of the Pushkin monument in Moscow to create meaning and the influence of other legendary Moscow characters on the reception of the Pushkin character.

Keywords: literary anecdote, popular anecdote, legend, popular Pushkin image, Pushkin's cult, Pushkin's statue, Moscow 